\title{
Negotiating the sacred body in Iranian cinema(s): National, physical and cinematic embodiment in Majid Majidi's Baran (2002)
}

\author{
Michelle Langford
}

\begin{abstract}
Any religious utterance, act or gesture, stands in the shadow of - more or less, but never totally avoidable — perversion, parody and kitsch, of blasphemy and idolatry. ${ }^{1}$
\end{abstract}

\section{Where have all the bodies gone? Modesty in Iranian cinema}

In the post-revolutionary period, Iranian cinema has been subject to strict Islamic censorship regulations that dictate what can and cannot be show on screen, particularly in terms of the representation of women and romantic relationships between men and women. The rules relating to the representation of women mirror, in a highly exaggerated way, the codes of modesty relating to women in society more generally. Censorship functions to ensure that both onscreen bodies and the bodies of viewers in the audience remain modest. These bodies must be protected from un-Islamic, profane, blasphemous or sacrilegious utterances, acts and gestures: primarily those related to sex and un-Islamic behaviour. This is achieved in life primarily through the veiling of female bodies, and on screen by a 'screening' of such acts and suggestions of sexuality that might cause one to become impure or 'haram'. The codes of modesty that prevail in society are greatly enhanced in the cinema, as all viewers are considered to be unrelated to the actors and characters who appear on screen. Modesty is maintained primarily by ensuring that onscreen women are appropriately veiled and clothed in loose-fitting clothing, and that physical contact between male and female bodies is avoided. Stories involving either emotional love or the suggestion of physical love between members of the opposite sex are generally avoided primarily due to the risk of violating the sanctity of pure, modest and Islamic bodies. ${ }^{2}$ Film form, that is, the technical and stylistic devices for creating meaning in cinema, according to Hamid Naficy has also undergone a radical process of Islamicisation, which obliges filmmakers to uphold the principles of Islam. ${ }^{3}$ In a religious context, where idolatry and imitating the creative act of 
God is considered to be highly sacrilegious, it is a wonder that the creative audio-visual medium of film has been adopted so readily as an instrument for consolidating the revolution and educating the population about proper Islamic morals and behaviour. Indeed, despite his constant critique of cinema during his years in exile, Ayatollah Khomeini is said to have seen the potential of the film medium for promoting revolutionary (primarily Islamic) values. ${ }^{4}$ Just as Western cinema and the popular and decadent pre-revolutionary cinema known as 'Film Farsi' were seen as an evil force that had corrupted the minds and bodies of the population during the Phalavi regime, in the post-revolutionary period, cinema was considered an appropriate vehicle for the purification of spectator's and by association the nation's mind, body and soul. With the enmeshing of state and religion brought about with the establishment of the theocratic government in 1979 and the establishment of Shari'a law, both individual and nation must necessarily reflect Islamic values.

Majidi Majidi's Baran (2001) is an extraordinary film which successfully depicts an adolescent man discovering his burgeoning sexuality, and falling in love with a beautiful young Afghan woman named Baran. Through the use of very clever and subtle cinematic devices, Majidi generates a deep sense of emotion and intimacy without ever showing any physical contact between the two, and without ever violating either the character's or the viewer's modesty. Additionally, by couching this love story in the broader context of the socio-economic condition of Afghan refugees in Iran, Majidi produces yet another level of discursive meaning where an ideal model of Islamic love and charity toward others may be perceived, effectively embodying a highly idealised conception of the nation. But, through its complex visceral engagement of the spectator's sensorium, Baran is a film that also explores the very limits of the sacred Iranian body on both the level of the national and individual citizenry. In this chapter, I wish to argue that through the simultaneous idealised embodiment of Iranian national Islamic values and the faltering, frail and very physical adolescent body of the central male character, Majidi is effectively negotiating the limits of the sacred body in Iranian cinema(s). I wish finally to demonstrate how film — which itself may be considered a body of sorts - may reach out figuratively to touch and move the bodies in the audience in ways that exceed simple observance of censorship regulations and generate vital connections between the viewers and the bodies on screen. In doing so, the film bears witness to the shadows that haunt any sacred utterance.

\section{Embodying the nation}

We see just such a reflection of individual and nation in the narrative trajectory of Baran. On one level, Majidi's film functions as an exemplary model of selfless devotion and modesty, particularly through its characterisation of the central male character Lateef, an adolescent gofer working on a building site on the 
outskirts of Tehran. The film traces his growing attachment to a young Afghan woman named Baran, who has come to the building site disguised as a young man named Rahmat in order to support her family following an accident that has rendered her father physically unable to work. Once Lateef discovers that Baran is really a woman, he is clearly struck by love's arrow and goes out of his way to please her and swoons in her presence. Eventually, however, Baran is forced to flee the building site as an illegal Afghan worker and Lateef goes in search of her. When he discovers the poor conditions in which she lives, and the harsh working conditions she endures, hauling large rocks from a rushing stream, he resolves to help her and her family by giving them all of his savings. Things do not go to plan, however, for Baran's father, Najaf, gives the money to his friend, Soltan, who needs it to return urgently to Afghanistan. Surprisingly, Lateef is not embittered by this situation, for he recognises that this man is just as desperate as Baran and her family. This is the first example of the self-sacrificing behaviour exhibited by Lateef throughout the film, putting collective needs above his own personal desires.

Lateef's behaviour also functions powerfully as an illustration of the Islamic principle of welcoming Muslim refugees and displaced peoples. During the Soviet occupation of Afghanistan (1979-89), Iran opened its borders to Afghan refugees who were classified by the newly formed Iranian government as Mohajerin, or 'involuntary religious migrants'. ${ }^{5}$ This principle, which is enshrined in the Quran was, according to Aldeeb Abu-Sahlieh, adopted in the second Islamic Declaration of Human Rights in 1981:

The homeland of Islam (dar-al-Islam) is one. It is a homeland for every Muslim, whose movement within [its domain] cannot be restricted by any geographical impediments nor political boundaries. Every Muslim country must receive any Muslims who emigrate thereto, or who enter it, as a brother welcomes his brother: 'Those who entered the city and the faith before them love those who flee unto them for refuge, and find it in their breasts no need for that which had been given them, but prefer the fugitives above themselves though poverty become their lot. And who is saved from his own avarice - such are they who are successful'... [Quran, 59:9] ${ }^{6}$

Lateef's first act of self-sacrifice, of preferring the fugitives above himself despite the certainty that this will increase his own poverty, tends to cast him as an ideal figure of the Islamic nation as the Quranic principles are powerfully embodied in him. This embodiment of Islamic values is further emphasised in his second self-sacrificing act, which becomes for Lateef an act of effacing his own individual identity.

Throughout the film, Majidi places emphasis on the themes of identity and identification in a number of ways that provide commentary on Iranian civil 
society and the shifting policies toward Afghan refugees in that society. The first instance occurs during the first few minutes of the film in a scene where Lateef goes to a supermarket to purchase food for the construction workers. Lateef has had to leave his identity card in order to secure credit at the store. The shopkeeper points out that the account is long overdue and demands payment. At risk is Lateef's identity card, and we recognise that he risks the security of his personal identity for the good of the collective (the labourers). Later, as Lateef is checking into a hotel, we see a man denied a bed for the night because he does not have an identification card. Additionally, on two occasions, the illegal Afghan workers (who do not have work permits) are forced to flee the building site when a government inspector comes to check for illegal workers. It becomes clear, when the foreman of the site is asked to sign a document stating that no illegal Afghan workers are employed on the site, that these Afghans are no longer treated as mohajerin who 'were issued with identification cards known as "blue cards", and granted indefinite permission to stay in Iran legally'. ${ }^{7}$ This detail of the film closely reflects Iran's changing policies toward Afghan refugees, who, after 1993, were no longer categorised as mohajerin, but simply as panahandegan (refugees), a term which 'was considered to have a pejorative nuance, even connoting impoverishment' ${ }^{8}$ These panahandegan were issued only with temporary registration cards, which made access to work and other civil services such as health care and education extremely limited. Lateef's strong sense of ideal Islamic devotion to the 'fugitives' is clearly being contrasted here with a view of the state's pragmatic approach to the refugee question. ${ }^{9}$ By extension, this would appear to suggest that, while the government of the Islamic Republic of Iran is constitutionally bound to abide by the principles of Islamic law, this may not necessarily be the case in practice, given the explicit removal of sacred significance from the Afghan refugees, which seems to ignore the passage from the Quran cited above. Majidi certainly provides an ideal role model in his film, however, by revealing a considerable gap between this ideal behaviour and the practices of the state, he has presented us with an allegorical figure aimed at representing the opposite of that which he would appear to represent. Lateef's behaviour is revealed to be explicitly and unrealistically ideal. The presentation of the ideal individual is used to highlight the flaws of the state.

Throughout the film, Lateef continues to practice such sacred beliefs toward his fugitive neighbours. This is brought to a climax with a highly symbolic and self-effacing gesture. Having already given away his entire savings, Lateef decides to sell his identity card in order to provide Baran and her family with the money they need to return to Afghanistan. In aesthetic terms, Majidi sets up this scene as though Lateef is making a dangerous journey into the underworld, further emphasising the austere and self-sacrificial nature of his gesture. As Lateef makes his way through the busy bazaar making enquiries, 
suddenly, two mysterious men begin to chase him through the narrow alleyways of the bazaar. But, after successfully giving them the slip, another man approaches him and urges Lateef to follow. He leads Lateef to a dark, cluttered old basement, which further emphasises the theme of his descent into the corrupt underbelly of Tehran. Here, another man purchases his identification card. A close-up of the card signals the symbolic intensity of this moment, as the man removes Lateef's photo, and metaphorically erases his identity with a quick flick of his grubby finger. This act of selling his identity card is a powerful gesture in which Lateef shows his preference for the fugitives above himself, even though this will certainly ensure his own poverty. Lateef is the very embodiment of the ideal national subject envisaged for the post-revolutionary Iranian cinema by Khomeini, yet ironically his perfection reveals the cracks and contradictions, the shadow of the very nation-state he is supposed to embody.

Lateef's developing model behaviour effectively serves as a critique of, rather than as an example of, state practice. Furthermore, by choosing to relinquish his identification/identity he is effectively rendered a non-citizen, like the Afghan refugees, and therefore it is questionable whether he even stands for the state after all, but rather becomes one of the many displaced people of the region.

\section{From embodied nation to embodied desire}

If Majidi presents Lateef as embodying the ideal, self-effacing values of Islam through his devotion to a series of Afghan refugees on a socio-political level, and, as I have shown it is possible to read this as signifying the opposite of what it appears to, then we need to investigate the various levels at which embodied desire is simultaneously effaced and achieved through the use of cinematic devices and a very complex deployment of the sound track.

Despite the necessary effacement of the physical, sexualised body in Iranian cinema according to the mandates of censorship, throughout Baran, Majidi manages powerfully to suggest the sexual awakening of a young adolescent man, taking him through stages of confused outbursts of anger in the all-male environment of the building site, to the discovery of his own capacity for love of a woman. By staging this inner journey on a building site - ostensibly a male dominated arena - in which a woman (Baran/Rahmat) intervenes, Majidi is effectively attempting to argue for the necessity of interaction between men and women in order for appropriate subject formation to take place and respect for one another to be achieved. Ironically, however, the woman arrives disguised as a man. Certainly, throughout the film Baran is literally figured as a domesticating, ordering and beautifying influence upon this rather ramshackle and chaotic space. Michael Fischer has suggested that Baran functions metaphorically as a cooling influence on Lateef's hot-blooded adolescent temper, ${ }^{10}$ although, I would argue, not without first firing him up. Thus, the 
film skirts the very edges of the sacred by alerting us to the pleasures of the flesh.

\section{Adolescent awakenings}

Even before the introduction of Baran/Rahmat to the film, we are provided with a glimpse of Lateef's burgeoning but floundering interest in the opposite sex. On his way back to the building site after shopping for bread, his attention is drawn by the sound of a woman giggling suggestively. We see him looking wistfully for a few seconds before the object of his gaze is revealed to be a young couple in a park playfully throwing a hat to one another. Such a playful but mediated tryst serves frequently in Iranian cinema as a coded substitute for a more intimate exchange, which is forbidden from the screen. The shot-reverse-shot structure of this brief scene leaves the viewer with no doubt that Lateef also longs for such female companionship as he chews distractedly on a piece of Afghan bread. Where the hat serves as a playful indirect signifier of forbidden physical contact - a reminder that the couple are not permitted to hold hands in public - the fleshy bread may be read as a cryptic clue or allegorical hieroglyph of Lateef's burgeoning desire to connect with another body. In fact, the bread is charged with such allegorical meaning from the very beginning of the film, when the viewer becomes attuned to the inherently fleshy qualities of raw dough. This is initially achieved through the evocative introduction of the soundtrack even before the first image has lit the screen. For a few seconds we hear some slapping sounds, not unlike the sound of a hand gently rubbing and slapping flesh. This is accompanied by breathing sounds, which are pushed to the very front of the soundscape, giving the cinema viewer the rather tactile sensation that someone is breathing in our ear. As with the momentary visual withholding of the source of the giggling woman, the few seconds during which vision is withheld allows the viewer's mind to wander, to invest these sounds with our own imaginations, to speculate on the kinds of images that may accompany them. In this sense, the black screen functions as a kind of veil, ${ }^{11}$ highlighting that something has been hidden from view, and signalling that we must engage both our minds and senses in order to delve into the deepest layers of meaning presented by the film. Following this aural 'tease', Majidi provides an answer to the sound puzzle, revealing the source of the sounds to be a baker kneading dough, rolling it out and slapping it onto the hot stone to be cooked. Even though this image manages to dispel the more titillating, and potentially sacrilegious suggestions provided by the sounds, Majidi has managed to attune the viewer to the particularly fleshy qualities of the dough, and predisposed us to read sensuality into Lateef's consumption of it in the scene described above. $^{12}$

Lateef's awakening adolescent desire is further emphasised moments later when he pauses to admire himself in a highly reflective glass door, fixing his 
hair, smiling and humming to himself, imagining perhaps that a girl might find him attractive. However, this moment of what may be described as narcissistic scopophilia - where he already perceives himself to be more man than he really is - is interrupted (metaphorically shattered) when a man pushes open the door from the inside, pauses to look at him suspiciously, thus bringing Lateef's self-reverie to an abrupt halt. His self-image is not yet fully formed as he balances on the cusp between adolescence and adulthood.

These are just the first of many clues that hint at Lateef's sexual awakening. On the building site, we witness other signs of his faltering and often misplaced attempts to assert his burgeoning masculinity. This fire that is burning inside him seems to function at times - such as those discussed above - as a calm, warming sensation, but at other times will flare out of control and provoke violent outbursts. Lateef frequently fights with his co-workers over highly insignificant matters, particularly once the young Rahmat (Baran disguised as a young man) comes to work on the building site. These outbursts become more frequent, particularly after Rahmat is given his job in the kitchen preparing meals and tea and Lateef must join the ranks of the labourers. Gradually, his outbursts become more focussed on Rahmat, showing ironically that he is learning to direct his adolescent rage. This rage, however, is suddenly turned to desire in a key moment when Lateef discovers that Rahmat is really a woman.

This scene is important for the way it is structured cinematically, for it is designed to generate a powerfully affective experience for the spectator as well as revealing the emotions that are being stirred up deep within Lateef's being. It also cleverly negotiates the censorship rules regarding the portrayal of women in Iranian cinema. The scene opens with a shot of Lateef going to fetch a heavy bag of cement. As he moves toward the camera, struggling to carry the heavy bag in his arms, wind blows a wave of white smoke across the screen, which irritates Lateef's eyes, causing a momentary loss of vision. The sound of the wind generates a highly mystical effect, appearing as a kind of energy that draws Lateef toward the kitchen area where Rahmat/Baran works. The soundtrack is then further layered with the distant sound of thunder, rain, and the faint sound of a woman humming. As Lateef blinks, a reverse shot of a curtain blowing in the wind briefly reveals the distant silhouette of a woman. Cut back to Lateef, still blinking he throws the bag of cement to the ground and rubs his eyes. The sound of wind continues to intensify, and having regained his vision, Lateef peers intensely toward the blowing curtain, the camera zooming toward him to indicate the sharpening of his vision. This movement is answered in the next reverse shot of the curtain, which now blows in slow motion, teasingly rising and lowering, providing another brief shot of the silhouette glimpsed earlier, but the curtain refuses to yield for more than a second or two. The movement and placement of the camera suggests a point of view shot, however when Lateef enters from screen right, we realise that Majidi has in fact placed us not with 
Lateef, but beside him, therefore implicating us within the scene. The following shot, however, does not yet reveal to us a clearer view of the scene behind the curtain, we see Lateef seeing, his eyes widening, fixing his gaze upon the scene before him. Finally, Majidi provides us with a shot of Baran brushing her long black tresses, humming to herself wistfully as she does so. She is framed and 'veiled' by a frosted window that barely separates either Lateef or the viewer from her modesty with backlighting providing a further distancing effect to protect the modesty of all. In this highly affective scene produced by sound, framing, camera movement and movement within the frame, not only are we encouraged to feel the passion that Lateef feels, but to experience images and sounds viscerally.

\section{Don't tell the mullahs!}

Throughout Baran, Majidi effectively uses images and sounds to engage the viewer in what Vivian Sobchack refers to as a 'cinesthetic' mode of embodied spectatorship. ${ }^{13}$ In her article, 'What my fingers knew', Sobchack argues that to experience a film is not simply a matter of 'seeing it'. Rather, our body functions as 'a 'third' term that both exceeds and yet is within representation'. ${ }^{14}$ That is, although our bodies are ostensibly located outside and separate from the representations that appear on screen, through the cinema's engagement of our multiple senses, our bodies are necessarily also inscribed into or take part in the representation itself. In addition, she writes: 'All the bodies in the film experience - those on-screen and off-screen (and possibly that of the screen itself) - are potentially subversive bodies. They have the capacity to function both figuratively and literally.' ${ }^{15}$ In coining the term 'cinesthesia', Sobchack draws on two psychoneurological conditions: synaesthesia and coenaesthesia. Synesthesia is an extreme, but rare condition in which the stimulation of one sense provokes a perception in another sense. Sobchack explains: 'Synaesthetes regularly, vividly, automatically, and consciously perceive sound as colour, or shapes as having a taste'. ${ }^{16}$ A less extreme form of this 'cross-modal transfer' takes place in figural language. According to George Lakoff and Mark Johnson, because metaphors originate in concrete, sensate experience, 'metaphor is experiential and visceral'. ${ }^{17}$ I would argue that the highly metaphorical film language used in Baran, combined with the clever use of off-screen sound, helps to engage the viewer in just this kind of cross-modal transfer. Not only does bread metaphorically evoke flesh, it does so largely because we have already heard/felt the potentially erotic fleshiness of the dough well before our sense of sight is brought into play. Similarly, in the scene in which Lateef discovers Baran's true identity, the enhanced sound of wind serves simultaneously as a metaphor for the swell of emotion being experienced by Lateef, and may cause a cross-modal sensation in the viewer of being touched by such a breeze. 
The dominant role played by sound in producing these cross-modal sensory affects in Baran also evokes the second bodily condition discussed by Sobchack. According to Sobchack, coenaesthesia is a common, yet under-recognised perceptual experience in which 'our equally available senses have the capacity to become variously heightened and diminished' ${ }^{18}$ This capacity is more evident in children where the hierarchical socialisation of the senses has not yet fully taken place, but given the right stimuli, this may also occur in adults. Cinema has the most wonderful capacity to do this, and certainly, as I have already shown, through his complex use of sound ${ }^{19}$ in Baran, Majidi certainly attempts to retrain his viewers' sensorium to privilege sound over or in addition to vision. This adds a highly affective and potentially erotic or subversive level of meaning to the film that plays off and against the pure, selfless devotion on a collective level, and the personal love for a woman on an individual level.

It is my contention that a figurative and literal exchange between potentially erotic bodies takes place in Baran. As in the scene discussed above, Majidi deploys complex cinematic techniques (sound, editing, camera and character placement) and stimulates our sensory organs (through evocative sounds and images) in order to weave the viewer into the very texture of the film. In doing so, he effectively allows the viewer to experience that which cannot be literally represented on screen. Our bodies effectively fill the gap imposed by censorship between the characters' bodies. In doing so, Majidi exposes the viewer to the possibility of what I would like to call 'sacrilegious affects', that is, a felt violation of the sacred modesty of the Iranian cinema screen. The cinema's potential for cross-modal transfer enables the superficial modesty of the on screen representation to be undermined by a transgressive potential in the aesthetic realm, capable of activating the forbidden (haram) sensations of the flesh.

Throughout the film, the sounds of wind, rain, thunder, running water, the fluttering of fabric and bird's wings, human breath, footsteps, voices, laughter and birds singing are all used to heighten the embodied sensory perceptions of the viewers and attune them to what must remain unrepresented, relegated to the space beyond the frame. Even a close-up of Lateef's finger wiping mud from a coin he finds in the street works to heighten our sense of touch. By the end of the film, our senses and emotions have become so heightened that we are prepared for the emotionally (and sexually) charged scene that closes the film. In this scene, Baran and her family are preparing to leave for Afghanistan and Lateef has come to their village to help. As Baran crosses the grey, muddy pathway she trips and the contents of her wicker bag spill out onto the ground. This functions as a moment of metaphorical explosion, betraying perhaps the feelings she has kept hidden throughout the film. We see among a variety of other fruits and vegetables, several bright red tomatoes, and some dried figs. Lateef rushes to Baran's aid and Majidi cuts to a close-up filmed in slow motion of Baran and Lateef picking up the spilled items. As their hands slowly and 
gracefully enter the frame a moment of tactile pleasure may be experienced by the viewer. Although, according to the rules of modesty, the characters do not physically touch, the framing of the image enables their images to overlap as they each reach for a ripe red tomato. They therefore 'touch' virtually in this brief and silent parting exchange, which is heightened by the contrast between the grey earth and the redness of the tomatoes, which provide a melodramatic sign of their passion. Here, the modest, restrained emotions depicted on screen overflow into the space between the viewer and the screen, into the dark space of the cinema where we may even 'steal' a publicly forbidden tactile moment. The almost-direct looks of the protagonists toward the camera that directly following this scene invite us to share in this intimate moment, further charging this affective relationship between the screen and the viewer. While, as I have shown, Baran adheres very strictly to Islamic censorship regulations, this relationship between screen and spectator set up by the film teeters on the precipice between the sacred and the sacrilegious, effectively pushing the limits of Islamic censorship that prevents intimacy between men and women from being depicted on screen. The modest bodies on screen are shadowed by the bodies of the spectators seated in the dark space of the cinema. But hush! Please don't tell the mullahs, because Iranian filmmakers have enough trouble with censorship as it is!

\section{Endnotes}

${ }^{1}$ Hent de Vries, 1999, Philosophy and the Turn to Religion, Baltimore: Johns Hopkins University Press, p. 11.

2 More recently, however, numerous films have dealt with the subject of romantic love, including the present film under discussion. Some of these films, which also fall into the genre of the 'spiritual film', use romantic love as a means for discovering divine love. Many take traditional Persian Sufi poetry as their model, pivoting around an ambiguous presentation of earthly and divine love. A recent example of such a film is God is Near (Khoda Nazdik Ast, Ali Vazirian, 2007).

3 Hamid Naficy, 2002, 'Islamicizing Film Culture in Iran: A Post-Khatami Update' in Richard Tapper (ed.) The New Iranian Cinema: Politics, Representation and Identity, London \& New York: I.B. Tauris, pp. 26-65.

4 This point is mentioned by numerous commentators including Richard Tapper in his introduction to The New Iranian Cinema, pp. 5-6; and Hamid Dabashi, 2001, Close Up Iranian Cinema Past, Present and Future, London: Verso, p. 32.

5 Mohammad Jalal Abbasi-Shavazi, Diana Glazebrook et al., 2005, 'Return to Afghanistan? A Study of Afghans Living in Tehran' Afghanistan Research Evaluation Unit, Faculty of Social Sciences, University of Tehran, p. 12.

6 Sami A. Aldeeb Abu-Sahlieh, 1996, 'The Islamic Conception of Migration' The International Migration Review, vol. 30, no. 1, pp. 37-57. p. 53. Emphasis added.

7 Abbasi-Shavazi et. al., op. cit., p. 12.

8 Ibid., p. 13.

${ }^{9}$ It should also be noted that the manager of the building site also treats the Afghans as mohajerin, paying them before the Iranian workers, much to the chagrin of those workers.

10 Michael M. J. Fisher, 2004, Mute Dreams, Blind Owls, and Dispersed Knowledges: Persian Poesis in the Transnational Circuitry, Durham \& London: Duke University Press. The metaphorical significance of Baran's name is twofold. It is at once the name of the river running through Karbul in Afghanistan and means 'rain' in Persian. 
11 Indeed, the blackness of the screen reminds me of the chador, the Islamic veil which is commonly used by devout Muslim women in Iran, and are required to be worn in all sacred spaces such as mosques and courtrooms. The chador is predominantly black, although a range of floral variants are often seen. 12 Later in the film, Majidi employs a process of metaphorical slippage, which functions to confirm the allegorical (rather than statically symbolic) nature of the aural and visual imagery. The complex soundscape of the building site recalls the opening sounds, and a number of times we see Baran and other characters mixing cement by hand, recalling the tactile process of making bread by mixing flour and water. Thus both bread and cement may substitute for forbidden physical contact between men and women.

13 Vivian Sobchack, 2000, 'What My Fingers Knew: The Cinesthetic Subject, or Vision in the Flesh' Senses of Cinema, vol. 5. http://www.sensesofcinema.com/contents/00/5/fingers.html. (Viewed 6 July 2004.)

14 Ibid.

15 Ibid.

16 Ibid.

17 Lakoff and Johnson quoted in Sobchack, ibid.

18 Sobchack, op. cit.

19 There are numerous other examples in the film, which I do not have space to discuss here. 